\title{
A Social Analysis of the Olive Oil Sector: The Role of Family Business
}

\author{
Idiano D'Adamo ${ }^{1,2}\left(\mathbb{D}\right.$, Pasquale Marcello Falcone ${ }^{1}\left(\mathbb{D}\right.$, Massimo Gastaldi $^{2}(\mathbb{D})$ and \\ Piergiuseppe Morone ${ }^{1, *}$
}

1 Department of Law and Economics, Unitelma Sapienza-University of Rome, Viale Regina Elena 295, 00161 Roma, Italy; idiano.dadamo@unitelmasapienza.it (I.D.); pasquale.falcone@unitelmasapienza.it (P.M.F.)

2 Department of Industrial and Information Engineering and Economics, University of L'Aquila,

Via G. Gronchi 18, 67100 L'Aquila, Italy; massimo.gastaldi@univaq.it

* Correspondence: piergiuseppe.morone@unitelmasapienza.it

Received: 10 July 2019; Accepted: 20 August 2019; Published: 22 August 2019

\begin{abstract}
Extra-virgin olive oil (EVOO) is one of the most popular products in Mediterranean diet. Spain produces about $52 \%$ of olive oil with the presence of larger firms; Italy follows with a share of $9 \%$ and a production structure characterized instead by small family businesses. A social analysis, based on a multiple-questionnaire, has analyzed the perspectives of 500 consumers conferring their olives to a family-owned olive oil mills (OOMs). This work aims to assess the role of family business evaluating the opportunities associated with the development of circular economy (CE) models. Results show that Italian consumers' preferences give attention to the use of natural resource and the olive oil is perceived as a natural product. In addition, family owned-OOMs provide a great sense of trust and the relevant role of family within the entire life cycle of olive oil is demonstrated. OOMs that work for residential market are strongly preferred to industrial ones being able to manage single lots of olives belonging to the same customers' land. The recovery of some by-products represents an opportunity for OOMs and policy support is required to favor the needed generational change, whose absence is perceived as a serious obstacle to the future development of the sector along circularity principles.
\end{abstract}

Keywords: circular economy; consumers' preferences; family business; olive oil; SWOT factors

\section{Introduction}

\subsection{Background}

The current unsustainable food production and consumption model pushes to increase the amount of food wastage [1], and about one-third of the food produced for human consumption is wasted globally [2]. This includes both avoidable and unavoidable food waste. As for the former, waste minimization strategies should be applied through the whole supply chain, whereas unavoidable food waste should be properly valorized to shift from a fossil-based linear economy to a sustainable circular economy (CE) [3,4]. The agriculture sector is characterized by the presence of several feedstocks suitable to be recovered from the energy and material side $[5,6]$. In this way, the application of CE models provides new opportunities for investors $[7,8]$. Some authors propose the concept of green economy as a means of societal marketing [9].

In the EU context, olive farming is very heterogeneous since there are several differences in terms of farming area and organization of the farm (i.e., traditional, intensive, and high-density plantations) [10]. The production of the olive oil is typically concentrated in the Mediterranean area (in particular Spain and Italy), but its consumption is widespread on a global level [11]. In fact, about $71 \%$ of olive oil 
production has a European origin with a dominant position occupied by Spain (1599 tons) with a global value equal to 3131 tons in 2018. Regarding its consumption, Europe covers about $53 \%$ and the first position is again taken by Spain (525 tons) with a global value equal to 2861 tons. Table 1 shows how Italy ranks second in terms of all variables analyzed (production, imports, exports, consumption) [12]. The European Parliamentary Research Service provides a comprehensive overview of the European Union's olive and olive oil sector. Plantations of olive cover a total area of 5 million hectares with a production value of over 7 billion $€$. The EU olive oil policy is addressed to maintain and strengthen its role in world markets by stimulating production of a high-quality product with benefits for all stakeholders involved (growers, processors, traders, and consumers) [13].

Table 1. Statistical data of olive oil market in 2018 (data in tons) [12].

\begin{tabular}{ccccccccc}
\hline Ranking & \multicolumn{2}{c}{ Production } & \multicolumn{2}{c}{ Imports } & \multicolumn{2}{c}{ Exports } & \multicolumn{2}{c}{ Consumption } \\
\hline 1 & Spain & 1599 & USA & 310 & Spain & 320 & Spain & 525 \\
2 & Italy & 265 & Italy & 85 & Italy & 186 & Italy & 500 \\
3 & Greece & 225 & Brazil & 78 & Tunisia & 130 & USA & 316 \\
& World & 3131 & World & 874 & World & 844 & World & 2861 \\
\hline
\end{tabular}

The average food price index is increased by around $11 \%$ in the EU, and by around $3 \%$ in world markets [14]. At the same time, the analysis of agriculture market has a complex nature due to the presence of a consistently large number of raw materials along the supply chain [15]. The level of acidity is the main characteristic of the olive oil: Extra-virgin olive oil (EVOO) has a free acidity, expressed as oleic acid, of not more than $0.8 \mathrm{~g}$ per $100 \mathrm{~g}$, while this parameter is equal to $2 \mathrm{~g}$ per $100 \mathrm{~g}$ for virgin olive oil (VOO) [16]. EVOO is considered a product essential in the Mediterranean diet [17]. The price of EVOO presents a great variability; yet, a range that varies between 7 to $8.7 €$ per liter can be identified and it is influenced mainly by the purchase cost of olives [18]. However, the price does not represent the main concern for consumers, that is, instead, represented by the risk of adulteration associated with EVOO [19]. For this motive, regulation 1096/2018 emanated by the European Commission requires to indicate the chemical characteristics and the year of harvesting of the final product on the label of EVOO [20]. The use of labelling increases the transparency and it is useful to guide consumers' decisions [21].

The olive oil industry, the object of this study, is characterized by the presence of several actors in the market [22]. Large firms adopt an aggressive pricing strategy with a widespread distribution of the product on the sales point [23]. Small and medium firms are oriented to produce a significantly lower amount of olive oil to preserve the quality of the product, with a customer target typically near to the production place [24]. Consumers are oriented to choose agricultural products coming from the country in which they live [25] and Italian EVOO is a globally well-known product [26]. The olive-oil sector is highly characterized by the presence of family business [27] and for this reason, it is worth studying the existence of the effect of a "family business brand" [28] on consumers" perceptions.

\subsection{Literature Review}

Olive oil is widely recognized around the world for its nutritional, health, and sensory properties [13]. Literature is focused on two directions: The first considers the phenomenon of family business using a specific olive oil market as an example and the second assesses how a particular sector of the economy can contribute to the realization of the circular economy principles.

Family businesses represent a key component of the European production system, making up more than $60 \%$ of all companies in Europe [29]. A typical issue characterizing these companies is represented by the succession; in fact, only $30 \%$ survive in the transition from the first to the second generation and the surviving rate goes down to $12 \%$ when moving from the second to the third generation [30]. Commitment is a key-pillar of a family business [31]: An important point that reflects the commitment is the use of the family name as a brand contributing also to the identity 
of the family itself [32]. Family businesses might perform differently from non-family businesses given that non-economic factors govern family firms' business decisions [33]. Such factors include: (i) Emotions [34]; (ii) feelings of responsibility [35]; and (iii) altruism [36].

The transition toward CE is unavoidable and family businesses could be frontrunners; the only concern is about the timeline of this change [37]. The three dimensions of family businesses, namely prominence (i.e., how the family as business owner is perceived by the community), continuity (i.e., making decisions based on sustainability of family business), and enrichment (i.e., the desire to maintain family harmony through altruistic behavior), regard the family nature of these companies and might act as a trigger that speeds up the implementation of CE in their business models [38].

The olive oil sector has a high presence of family businesses. In Spain, about $17 \%$ of people working in this sector are non-family members, but in several countries, this share stands at only $1 \%$ [39]. As mentioned, family-controlled organizations present specific characteristics. In particular, some authors underlined the importance of a distinct family image in the community showing how the business could be interpreted as an extension of such family image [33]. In addition, other authors focused on the sense of pride and the preservation of the family's good name for future generations [40].

With specific reference to the EVOO sector, small-scale low-productivity farms persist despite modernization pressures and policy pitfalls. The transformation of this agricultural product has a cultural origin and can be defined as a social event [41]. In addition, the olive oil market is subject to significant fluctuations due to several factors, such as extreme weather conditions, plant disease outbreak, and cyclical alternation of good and poor harvests [39]. In this scenario, some Italian family businesses involved in the olive-oil sector struggle to survive due to their limited financial capacity, hence favoring the market penetration of foreign companies, which can often sell their product at a lower price [13]. Under these highly competitive economic conditions, the application of CE principles could favor the development of alternative business model, also based on a tight control of product's origin and traceability, which would in turn reduce consumers' perceived risk [42].

In a circular model, waste generated by the olive oil industry can be, if properly managed, used as raw material to produce synthetic natural gas and liquid biofuels bringing both economic and environmental benefits $[43,44]$. Farmers play a key role in the olive industry to enhance the usage of secondary raw materials by adapting their business model towards CE paradigm based on their personal drivers and stakeholders collaboration along the entire value chain $[45,46]$. Using materials efficiently is an essential business strategy that, in turn, would enhance the promotion of CE to address the concern of resources sustainability $[47,48]$.

Scholars have analyzed the olive oil sector in terms of CE from several perspectives. By-products and waste coming from olive production and olive oil industry are characterized by the presence of phytotoxic components representing an environmental issue [49]. Anaerobic digestion is a suitable technology to produce biogas [50] and pyrolysis is a treatment to recover rich value-added chemical groups from common olive oil residues [51]. Therefore, a consistent number of resources can be valorized providing opportunities for the olive oil industry [52] and eliminating a source of potential pollution [53]. Industrial waste and by-products, coming from both olive production and the olive oil industry, contain highly valuable components that can also be phytotoxic [49]. Olive mill wastewater (OMW) is produced during the production of olive oil. Its disposal is a major environmental issue in Mediterranean countries, despite the availability of a large number of technologies suitable to treat it [54]. Specifically, the absence of economic models useful for assessing the feasibility of these processes represents a relevant gap. Some economic benefits are: (i) The reduction of waste disposal cost and (ii) the reuse in the production of foods with health properties characterized by phenolic compounds [55]. The recovery of agricultural residues (e.g., olive grove pruning) and by-products (e.g., olive pomace) aims to close the loop favoring the development of CE models in agriculture. By-products (such as virgin pomace, vegetation water, and pits) coming from the olive industry are no longer considered as an issue for the environment, yet can represent an economic opportunity [56]. 


\subsection{Contribution}

In the EU context, olive farming is very heterogeneous since there are several differences in terms of farming size and organization (i.e., traditional, intensive, and high-density plantations) [10]. The Italian olive sector is characterized by an intense fragmentation of businesses, often family-controlled, and by the prevalence of traditional plantings (mostly hand harvested) [57].

Against this background, and building on the Italian consumers' preferences in the olive oil sector, the aim of this study is to assess whether the family nature of a firm has a positive effect on trust and purchase intention of consumers that conferred olives to OOMs managed by family businesses, evaluating the opportunity associated with the CE models. Interviewees were selected on the base of a convenience sampling.

This work embraces a holistic approach, integrating a questionnaire-based methodology with a strengths, weaknesses, opportunities, and threats (SWOT) framework to exploit a large set of perspectives coming from 500 consumers in order to generate valuable information for providing answers to the following questions:

RQ1: What is the role of family business within the olive oil sector? What are the strengths, weaknesses, opportunities, and threats in reference to the relationship between OOM owners and land owners?

RQ2: Does olive oil residues provide prospects according to the CE models?

The work is organized in the following way: Section 2 introduces the case-study and the methods used and Section 3 shows the main findings obtained by the survey. Section 4 provides some concluding remarks.

\section{Materials and Methods}

Our objective here is to exemplify some connections between the consumers' preferences and OOMs managed by family businesses within a strategic pillar of the agriculture, namely the olive oil sector. The survey involves three typologies of subjects:

(i) Consumer of family-owned OOMs, which is also a producer of olives.

(ii) Consumer of family-owned OOMs, who buys olives from a producer in order to crush them in the OOM.

(iii) Final consumers of olive oil.

In this work, the term consumer includes the three typologies of subjects cited above, in accordance with the existing literature $[18,58,59]$. In our study, we build upon a questionnaire-based research methodology to understand the extent to which the consumers' insights could provide information on strengths, weaknesses, opportunities, and threats of the sector investigated [60,61]. Thus, a three-step methodology was followed (Figure 1):

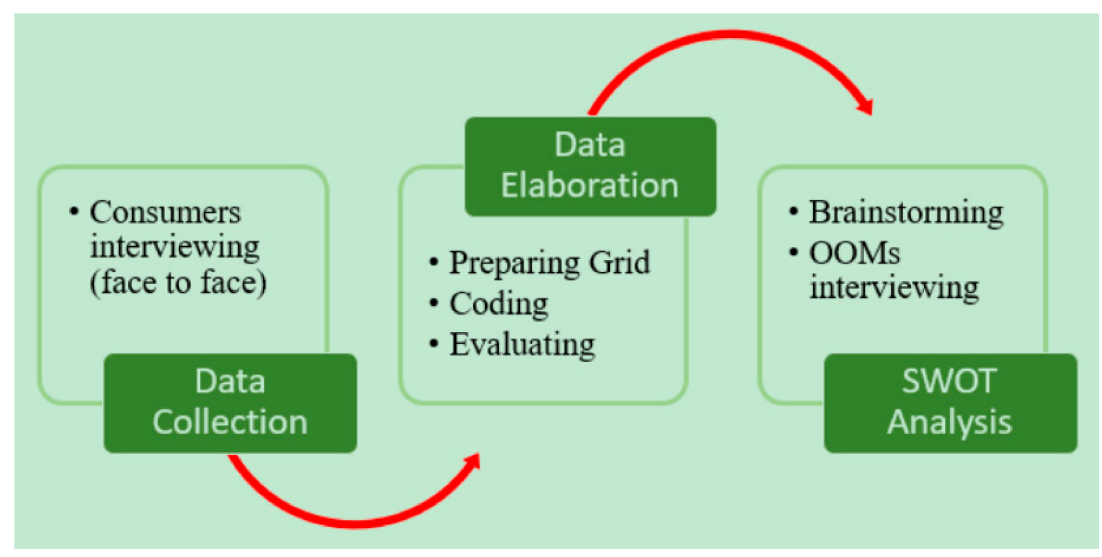

Figure 1. Methodological framework. 


\subsection{First Step-Data Collection}

In the first step of our investigation, we carried out a survey involving 500 consumers of different ages and levels of education (Figure 2). This number of interviewees is adequate for the analysis of this sector and aligned with earlier studies conducted in Spain [62].

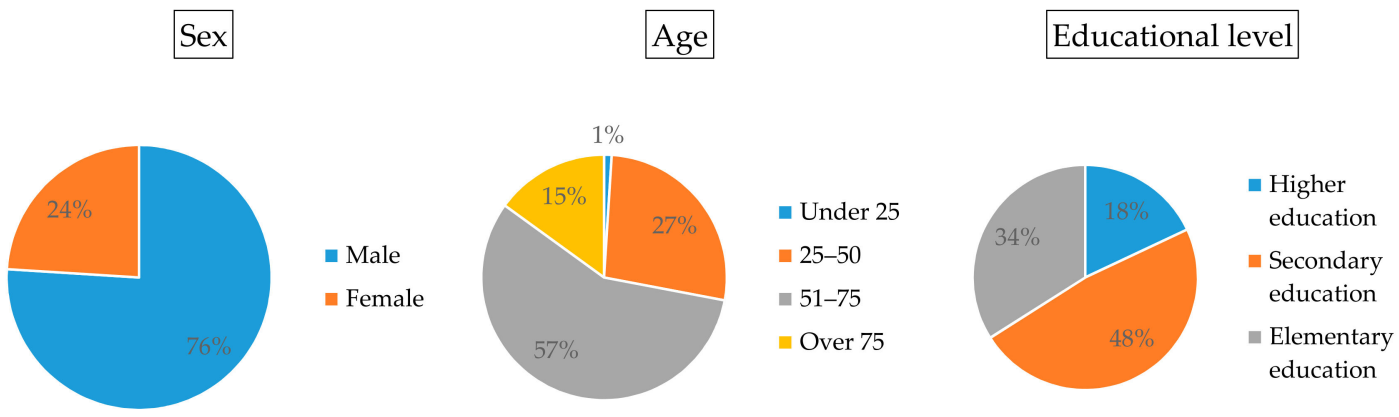

Figure 2. Respondents' characteristics.

Consumers were approached during their experience in the OOMs with the aim of conducting a face to face interview (hence, interviewees were selected on the base of a convenience sampling [63]). The interviews were carried out over the period October-December 2018 and each interview took, on average, one hour. The names and identifying information of the 500 respondents were anonymized for privacy reasons. The 500 interviews were conducted in two family OMMs located in Abruzzo and Puglia. The choice of the two OMMs for conducting interviews was built upon expediency reasons (e.g., presence of members of the research group on the site, availability of facilities for conducting interviews, OMMs owner availability to participate in the field analysis). Table 1 has emphasized the importance of Italy in the market. Specifically, the domestic olive production covers roughly 1,700,000 ha, $80 \%$ of which are located in the southern part of the country (i.e., Abruzzo, Puglia, Calabria, and Sicily) [12]. The respondents were asked to first provide a value judgement on the level of relevance of 20 different statements assigning a value from $0 \%$ (the minimum level of relevance) to $100 \%$ (the maximum level of relevance)-Table 2.

Table 2. Questionnaire—simple answer.

\begin{tabular}{|c|c|c|}
\hline No. & Question (What Is the Relevance/Importance ... ) & Value $(0-100 \%)$ \\
\hline$(1)$ & to have an OOM located near your land? & \\
\hline$(2)$ & that your family participates to the collected phase? & \\
\hline (3) & to know the date of crushing of olives? & \\
\hline$(4)$ & of delay time between collected phase and crushing one? & \\
\hline (5) & to give the product into the OOM warehouse before of crushing date? & \\
\hline$(6)$ & to choose the processing line (traditional or continuous)? & \\
\hline$(7)$ & to obtain olive oil only by your olives? & \\
\hline$(8)$ & to have olive oil based on natural resources? & \\
\hline (9) & to see the entire process of production? & \\
\hline$(10)$ & to know the different steps of the process? & \\
\hline$(11)$ & of the presence of family-members during the production phase? & \\
\hline$(12)$ & to sell olive oil to relatives/friends? & \\
\hline$(13)$ & of the quality obtained by the crushing of olives? & \\
\hline$(14)$ & of the yield obtained by the crushing of olives? & \\
\hline (15) & of the presence of family-members during the administrative phase? & \\
\hline$(16)$ & that your friends come at the same OOM? & \\
\hline$(17)$ & of costs required by OOM? & \\
\hline (18) & to be helped by your family members during the olive oil production? & \\
\hline (19) & of labelling on the final product during selling phase? & \\
\hline$(20)$ & to use own olive oil for personal needs? & \\
\hline
\end{tabular}


Then, they were asked to answer to a second questionnaire composed by other 20 multiple choice questions in which the respondent indicated a single preference-Table 3.

Table 3. Questionnaire-multiple answer.

\begin{tabular}{|c|c|c|}
\hline No. & Question & Sign an $X$ \\
\hline$(21)$ & Which is the most important feature of the olive oil? & \\
\hline (a) & Its quality & \\
\hline (b) & Its yield & \\
\hline (c) & Its production cost & \\
\hline$(22)$ & Why do you choose the traditional line? & \\
\hline (a) & I'm used to that taste & \\
\hline (b) & I prefer its quality & \\
\hline (c) & I prefer to have a higher yield & \\
\hline (23) & Why do you choose the continuous line? & \\
\hline (a) & I prefer to have a lower cost & \\
\hline (b) & I prefer its quality & \\
\hline (c) & I wish to try a new product & \\
\hline$(24)$ & How many years your family comes in this OOM? & \\
\hline (a) & Less than 5 years & \\
\hline (b) & Between 5 and 15 years & \\
\hline (c) & More than 15 years & \\
\hline$(25)$ & What is the positive main characteristic of this OOM? & \\
\hline (a) & The presence of family members give me a sense of confidence & \\
\hline (b) & The correct equilibrium between price/quality/yield & \\
\hline (c) & Its proximity to my land & \\
\hline (26) & What is the negative main characteristic of this OOM? & \\
\hline (a) & An insufficient equilibrium between price/quality/yield & \\
\hline (b) & New technologies could reduce production time & \\
\hline (c) & The presence of rules to follow & \\
\hline$(27)$ & What is the information required during selling phase? & \\
\hline (a) & EVOO & \\
\hline (b) & Own olives & \\
\hline (c) & The name of OOM & \\
\hline$(28)$ & Why the production of olive oil is relevant? & \\
\hline (a) & Medical properties & \\
\hline (b) & Additional income & \\
\hline (c) & Food of own land & \\
\hline (29) & What is the relevance of olive oil sector in a political perspective? & \\
\hline (a) & High & \\
\hline (b) & Medium & \\
\hline (c) & Low & \\
\hline$(30)$ & What is the use of olive oil? & \\
\hline (a) & Occasional & \\
\hline (b) & Once a day & \\
\hline (c) & Twice daily & \\
\hline$(31)$ & What is the relevance of the labelling? & \\
\hline (a) & High & \\
\hline (b) & Medium & \\
\hline (c) & Low & \\
\hline$(32)$ & How do you evaluate the access to public funding? & \\
\hline (a) & Easy & \\
\hline (b) & Not easy not difficult & \\
\hline (c) & Difficult & \\
\hline (33) & Is relevant for an OOM to have a green image? & \\
\hline (a) & High & \\
\hline (b) & Medium & \\
\hline (c) & Low & \\
\hline
\end{tabular}


Table 3. Cont.

\begin{tabular}{ll}
\hline No. & \multicolumn{1}{c}{ Question } \\
\hline (34) The period of low production is determined by? \\
(a) Climate change \\
(b) Chemical products \\
(c) Inadequate pruning of olive trees \\
(35) Biologic is an important characteristic of olive oil? \\
(a) Yes \\
(b) Indifferent \\
(c) No \\
(36) The recovery of olive mill wastewater provides: \\
(a) Economic opportunities \\
(b) Environmental issues \\
(c) Both \\
(37) What is the importance to use natural resources? \\
(a) High \\
(b) Medium \\
(c) Low \\
(38) The recovery of virgin pomace olive provides \\
(a) Economic opportunities \\
(b) Environmental issues \\
(c) Both \\
(39) What is the importance of new local opportunities of work? \\
(a) High \\
(b) Medium \\
(c) Low \\
(40) Having public funds available, who are the beneficiaries? \\
(a) Only land owners \\
(b) Only OOM owners \\
(c) Both land and OOM owners \\
\hline
\end{tabular}

\subsection{Second Step-Data Elaboration}

In the second step, we elaborated the information included in the questionnaires by first preparing a simple grid in an Excel File to collate and process the data provided by the interviewees. The preparation of the grid was followed by the design of a simple coding system aimed at categorizing the qualitative nature of the data in order to facilitate the analysis. This was particularly useful for the categorization of the socio-demographic characteristics of respondents (i.e., age, level of education, gender, etc.) [64]. Once the data have been organized and coded, they are ready to be evaluated. The analysis of data, in terms of summary statistics, allowed us to detect the key characteristics of the sample and look for relevant patterns to be used in the third step of our investigation, namely the SWOT analysis.

\subsection{Third Step-SWOT Analysis}

In the last step of our investigation, and building on the preliminary insights coming from the analysis of the questionnaire data, we defined SWOT factors with the aim of providing detailed understandings on the internal (i.e., strengths and weaknesses) and external (i.e., opportunities and threats) conditions of the olive oil sector. To this end, we utilized a triangulation-based strategy that enabled us to provide robustness to our findings [65]. Specifically, after having derived some relevant results from the questionnaire data, we used an iterative method of brainstorming between the four authors and other scholars belonging to the same research group in order to isolate the most relevant aspects characterizing the sector under investigation. To corroborate these preliminary findings and understand their actual relevance, we administered two follow up questionnaires to an OOM owner and a land owner with a long-term experience in the sector. Specifically, they were asked to validate or confute the outcomes preliminarily identified and categorize them according to the SWOT matrix. 


\section{Results}

\subsection{Findings Based on a Survey on Consumers' Preferences}

Results of responses obtained by the survey of 500 interviewees are proposed in Figure 3 (simple answer) and Figure 4 (multiple answer).

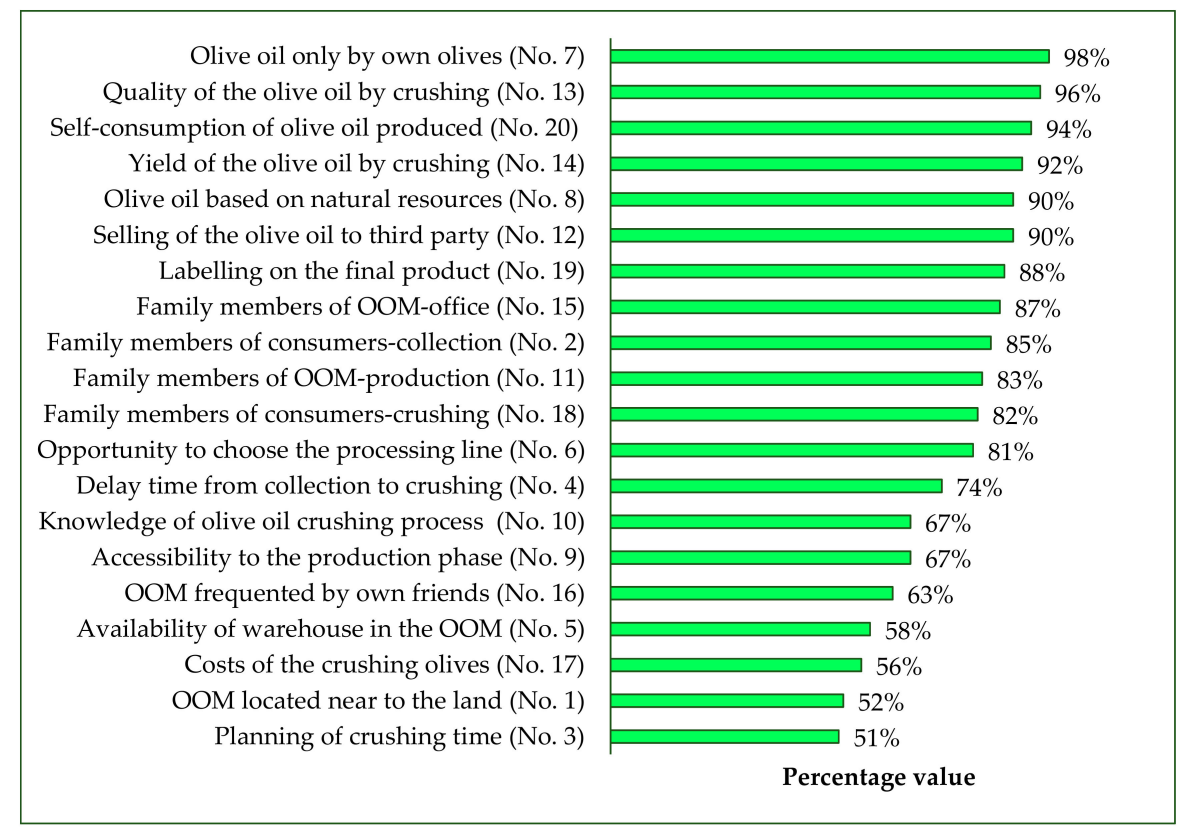

Figure 3. Results—simple answer.
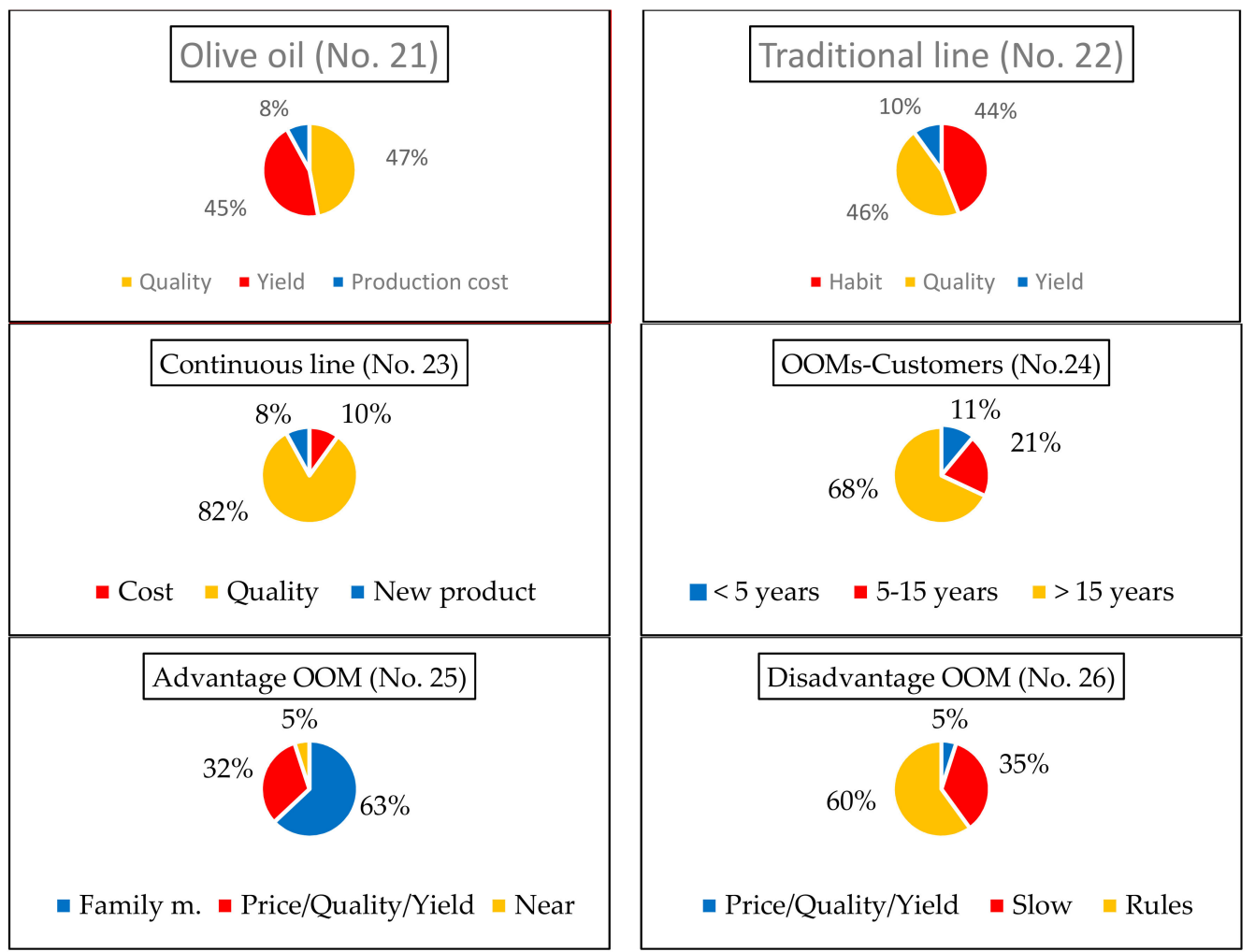

Figure 4. Cont. 


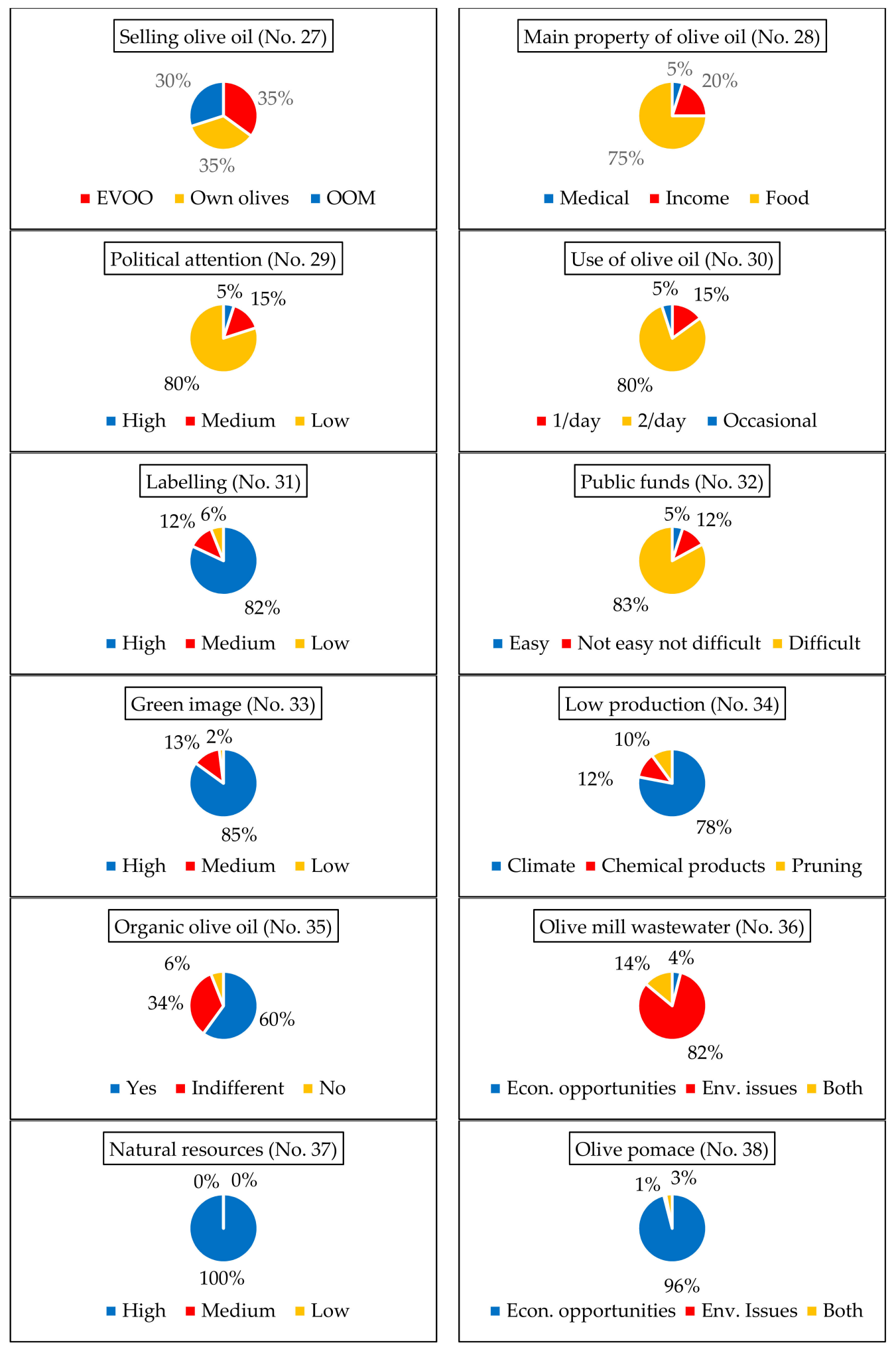

Figure 4. Cont. 

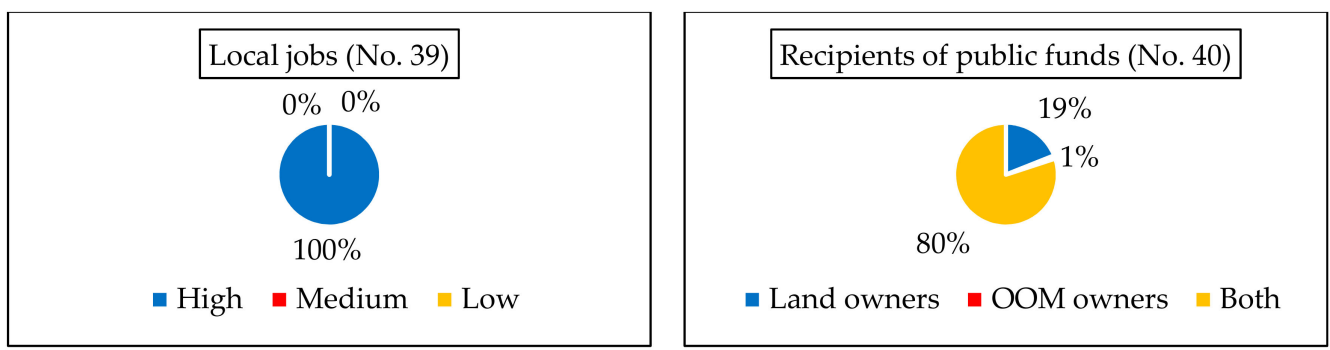

Figure 4. Results-multiple answer.

OOMs that work for industrial uses can jointly crush lots of olives belonging to different people. The reduction of costs is the final aim. Instead, OOMs that work for residential uses manage single lots of olives and each of them belongs to the same person. The survey underlines that this characteristic is the most relevant (No. 7).

Two characteristics of olive oil relevant for consumers are: (i) Quality and (ii) yield (No. 21) [19]. Typically, people taste the genuineness of the freshly squeezed olive oil and shares it with their own family and friends. Consequently, the quality assumes a key-role and it is associated with a product classified as EVOO (No. 13) [66]. The olive oil is used daily during both lunch and dinner (No. 30).

In addition, it is possible to calculate the yield of the olives from the crushing process that defines the amount of olive oil produced [18]. It is compared with values obtained during the past years and/or with average values registered in this olive oil campaign (No. 14). Finally, customers provide feedback on the experience in the OOM during the time of elaboration of the invoice. Private facts and events are shared during all phases of the process and this is determined by the number of years that linked customers to the OOM. In fact, about $68 \%$ of interviewees were consumers for almost 15 years (No. 24). These people have seen the new generation growth and the generational change is not an obstacle to the development of the activity $[30,40]$. The presence of family members in the activity of OOM was defined as its main advantage by about $63 \%$ of interviewees. It had a weight greater in comparison to the correct equilibrium between yield, quality, and cost (No. 25).

The idea of the social event proposed in [41] is also confirmed in this work. The relevance of family members concerns, from one side, the owners of OOMs (No. 11 and No. 15) and from the other side, the components of own family (No. 2 and No. 18) [33]. Speaking of olive oil, the consumption of the product coming from own land is the main property evaluated by consumers (No. 28). The additional income could be defined as marginal in comparison to this aspect, but it is relevant in absolute terms. In fact, the olive oil can be sold to own relatives/friends permitting the recovery of a share of costs incurred by producers of olives (No. 12) [67]. During this selling phase, the availability of EVOO (and not of VOO) has the same weight of other two aspects: (i) The crushing concerns only own olives and (ii) the cleaning of the plants and the constant control operated by the workers of the OOM (No. 27). In this direction, the labelling on the final product gives a sense of confidence to final consumers (No. 31) [68]. In fact, it is assumed that a clear responsibility of the properties of olive oil is declared in this label (No. 19). Another interesting point of reflection concerns consumers' perception regarding the absence of political support to the sector (No. 29) [27,69]. In the past, economic subsidies were provided to the land owners, but currently these values have been significantly reduced and at the same time, the bureaucratic phase is extremely complex (No. 32). Interviewees agree to consider the need of a new policy support that must include not only land owners, but also OOMs owners. In fact, the last periods are characterized by one year of high production and one of low production (No. 40). In addition, there is the opportunity to develop new job opportunities (No. 39). All are in agreement with this idea and an incredible $100 \%$ is reached for this response. OOM is also a meeting place for people. In fact, they remain in this place for a period of time greater than necessary (No. 16). For this reason, it is not important that OOM can be far from one's own land (No. 1).

A surprising result of this survey is the low relevance assigned to the costs for the crushing of olives (No. 17 and No. 21) [70]. Some reflections are proposed by the same consumers. It is significantly 
lower than that associated with the phases of production and collection of the olives and it is compared with one of the previous years (it is maintained fixed in both OOMs during the olive campaign in which the survey has been conducted). In addition, there is the opportunity to pay on credit.

Another element of analysis is the presence of both production lines in these OOMs. Currently, people prefer using the traditional line because they are used to that taste of the olive oil, also characterized by a high quality in their perspective (No. 22). The same response is also given by consumers that choose the continuous line. They indicate a slightly lower yield that is compensated by the reduction of the product residue on the bottom of containers over time (No. 23).

The strategy of family businesses is clear: It is not possible to ascertain that the quality of olive oils is superior if produced in one or the other production line, as this would depend exclusively on the individual taste of consumers. The very same olives, crushed in different production lines, would provide a different final product: Pastier with a traditional line and lighter with a continuous one. The innovative idea can be seen to have two distinct products by the same olives. This permits us to saturate both lines, avoiding working on three shifts (but only on two), with a specific characteristic on the market of OOMs (No. 6) and reducing the time that separates collection from crushing (No. 4). In this transition, the explanation of the process phases becomes relevant (No. 10).

The presence of strict rules is perceived as the main negative characteristic of these OOMs (No. 26). In fact, the crushing of olives must be planned (No. 3), the conferment of the product can take place only in certain periods (No. 5), and should be implemented under rigorous safety conditions (No. 9).

Furthermore, a special focus is dedicated to the organic product [71,72]. Among respondents prevails the idea that consumers give a great importance to natural resources (No. 37) and that olive oil obtained by the crushing of own olives is a good example of the use natural resources (No. 8). Moreover, interviewees are aware of climate change's negative consequences on productivity (No. 34). In particular, $60 \%$ of interviewees have defined that the characteristic of olive oil to be organic is relevant and $34 \%$ is, instead, indifferent towards this theme (No. 35). Consequently, the first element of olive oil is its acidity and if it is classified as EVOO [18,21]; in fact, consumers use typically olive oil for own needs (No. 20). They know very well products/materials used for fertilizing olive trees and probably also for this aspect, the biological characteristic has a minor importance. At the same time, an organic product does not indicate that olive oil is also an extra-virgin. An organic product can be obtained by a continuous line process but only some consumers opt to choose it.

Finally, the role of CE models is investigated in the olive oil sector. The interviewees have provided the maximum priority to the use of natural resources (No. 37) and $85 \%$ of them have declared the relevance of green image played by OOMs (No. 33). Some good practices are: (i) The management of by-products with an environmentally friendly approach oriented to recovery materials but also to produce renewable energy; (ii) the minimization of waste generated; and (iii) an adequate separation of several typologies of waste. By-products are considered capable of activating processes or procedures to reduce the costs of OOMs. Both virgin pomace and olive pits are sold and $96 \%$ of interviewees recognize an economic value to the olive pomace (No. 38). It has a high calorific value, in particular if coming from the traditional process (in this case, it has a selling price about four times higher than the one from the continuous line). Olive pits can be recovered and transformed in lampante olive oil with free acidity in the range of $2 \%$ [12]. Instead, the management of the OMW worries citizens: The authorities release sanctions towards OOMs responsible of environmental crimes. This probably contributes to the negative perceptions of consumers towards this by-product: $82 \%$ of them consider the OMW as an environmental issue (No. 36). The cost concerning this by-product changes significantly across regions (in Puglia, it is significantly lower than in Abruzzo due to different quantity to manage) and upon the amount recovered each time. 


\subsection{The Definition of SWOT Factors}

The analysis of questionnaires provides the support to define the SWOT factors related to the relationship between two actors of the olive oil sector: (i) OOM owners and (ii) land owners-Table 4 . The definition of SWOT factors is the first step of a SWOT analysis [73].

Table 4. Strengths, weaknesses, opportunities, and threats (SWOT) factors.

\begin{tabular}{ll}
\hline \multicolumn{1}{c}{ Strengths } & \multicolumn{1}{c}{ Weaknesses } \\
\hline $\begin{array}{l}\text { Self-consumption own product } \\
\text { Additional incomes } \\
\text { Transparency (production process) } \\
\text { Yield olive oil }\end{array}$ & $\begin{array}{l}\text { Low production } \\
\text { High costs (Labor, Administrative) } \\
\text { Quality olive oil } \\
\text { OOMan risks during production process } \\
\text { Difficult access to public/private funds }\end{array}$ \\
$\begin{array}{l}\text { OOM managed by family business } \\
\text { Product differentiation }\end{array}$ & \\
\hline \multicolumn{1}{c}{ Opportunities } & \\
\hline $\begin{array}{l}\text { Circular economy model } \\
\text { Green image }\end{array}$ & Climate change \\
Social event \\
Local economic opportunities \\
Local job growth \\
Labelling (new potential customers) \\
Olive oil based on natural resources \\
Family reunification
\end{tabular}

The olive oil sector is a traditional market, in which the Italian brand is globally well-known. The reduction of production costs operated by competitive countries (e.g., Spain) has determined a change in the distribution market [74]. Some OOMs have introduced innovative technologies in order to improve their processing lines. In fact, the traditional line is no longer produced and regulatory guidelines push modernization to avoid direct contact between human operators and the intermediate/final product during production phases.

A great issue of concern is represented by the old age that characterize all consumers that conferred olives to OOM. The absence of a generational change is perceived as an obstacle to the development of the sector and policy-makers intervention to mitigate this aspect is highly desired. Olive oil is a vital sector considering its property in terms of Mediterranean diet and health benefits $[17,21]$. Consumers assign the maximum relevance to a product obtained through olives grown in their own land. This requires several physical and economic sacrifices. In fact, a good quality of olive oil does not depend only by the crushing operated by OOMs. It is based on soil and plant fertilization, tree pruning, and olive harvest that requires specific technical procedure to follow. During these steps, consumers can choose how much natural resources to use and all consumers seem to agree on the importance of valorize natural resources.

In this way, the topic can be framed in terms of sustainability. From a social perspective, there are advantages including family reunification, revitalization of rural areas, and the creation of new jobs (currently there are cases in which olives are not collected due to the lack labor force). At the same time, there is a great limit represented by the generational change [75]. From an economic perspective, the EVOO margin of profits are typically low considering the high costs incurred during the production and the pressure on price markup imposed by market competitiveness (e.g., in the presence of too high prices consumers would revert to lower quality products) [18]. Also, the value of turnover is reduced due to the seasonality of the product and the particularly low amount of olives treated in some years. The high quality of Italian EVOO is the distinctive element with respect to olive oil produced in other countries and this aspect can be enhanced by rigorous controls and verified by labelling. The literature 
indicates clearly that consumers are willing to pay a higher price for EVOO and new opportunities are associated also with the production of the organic EVOO [76,77]. From an environmental perspective, the main risks are associated with the management of by-products coming from both olive production and olive oil industry. However, by-products contain highly valuable components and so may be extremely useful to generate energy and water from renewable resources and recycling processes, respectively. In addition, all waste streams of the OOMs require inspective controls and each has a technology of recovery suitable to perform the models of CE [45,49]. This transition can be pushed by policy-makers favoring the cooperation among several OOMs to stimulate solid partnerships with firms active in the recovery activities. Moreover, it is necessary to reduce the emissions linked to transportation.

Finally, it has been observed how the presence of several OOMs stimulates the competition, in turn, pushing prices down and quality up. In fact, the shorter the time intercurrent between the collection phase and crushing phase is, the higher the final product quality will be. In addition, the development of intensive olive groves could reduce the cost of production for several Italian industrial and bottling brands, as the Spanish experience has demonstrated. Moreover, assigning uncultivated lands to young farmers could prompt the development of small and more innovative firms.

\section{Conclusions}

The sector of olive oil has a high level of competition, in which large firms crush olives coming from several regions to optimize the processing time, thus reducing production costs. In this way, the final price of olive oil can be kept low and this attracts consumers. In this global context, Italian producers of EVOO, often characterized by small local family businesses, struggle to be competitive keeping high the quality of their product.

The picture emerged from this study is a mixed one. Although the global competition puts the Italian model under pressure, three crucial findings emerged: (i) The attention of consumers towards the natural resources, (ii) the sense of family associated with the life cycle of olive oil, and (iii) the strategic role played by OOMs managed by family business that give a great sense of trust. In particular, the main advantage of an OOM that works for local market is to only crush olives coming from trusted local land-owners.

The SWOT analysis performed in this study also showed how the application of CE models permits the transformation of solid and liquid waste associated with the olive oil chain into opportunities, including: (i) The recovery of energy of the biomass from both olive groves and virgin olive pomace; (ii) the recovery of water from olive oil wastewater; and (iii) the recovery of value-added products (e.g., olive pits). These opportunities can provide additional incomes for the OOMs, but the feasibility of recovery plants is associated with economies of scale. For this reason, the cooperation among small producers is necessary particularly in small areas (e.g., Abruzzo), while large areas (e.g., Puglia) have the availability of a great amount of raw materials.

The analysis presented in this paper focused on social aspects. Future research should go in the direction of complementing this study with a thorough sustainability assessment, where economic and environmental aspects are taken in due consideration. Moving along this line of research, the impact of $\mathrm{CE}$ principles could be further investigated as a way of creating valuable synergies among OOMs, causing the Italian high-quality production model to regain global competitiveness.

Author Contributions: Conceptualization, I.D. and P.M.F.; methodology, I.D. and P.M.F.; validation, I.D. and P.M.F.; formal analysis I.D.; data curation, P.M.F.; writing — original draft preparation, I.D. and P.M.F.; writing—review and editing, I.D., P.M.F., M.G., and P.M.; visualization, M.G. and P.M.; supervision, M.G. and P.M.; project administration, M.G. and P.M.

Funding: This research received no external funding.

Acknowledgments: A special thanks to all interviewees and OOMs involved for their precious support. We are grateful to Oleficio Andreini Srl-Vasto $(\mathrm{CH})$, Italy for the Graphical abstract.

Conflicts of Interest: The authors declare no conflict of interest. 


\section{Abbreviation List}

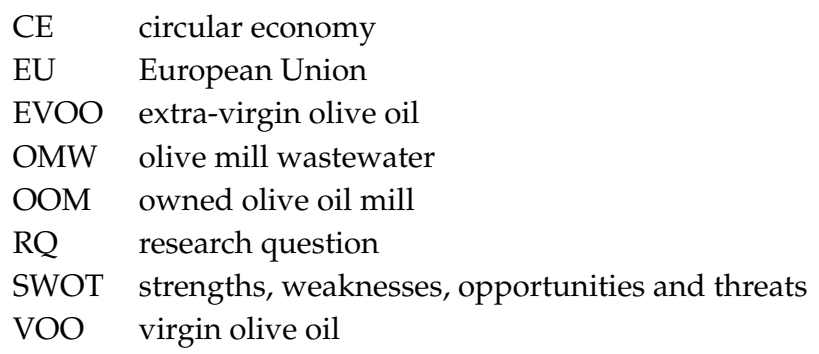

\section{References}

1. Morone, P.; Falcone, P.M.; Imbert, E.; Morone, A. Does food sharing lead to food waste reduction? An experimental analysis to assess challenges and opportunities of a new consumption model. J. Clean. Prod. 2018, 185, 749-760. [CrossRef]

2. FAO. SAVE FOOD: Global Initiative on Food Loss and Waste Reduction. Food and Agriculture Organization of the United Nations. Available online: http://www.fao.org/save-food/resources/keyfindings/en/ (accessed on 1 July 2019).

3. Stewart, R.; Niero, M. Circular economy in corporate sustainability strategies: A review of corporate sustainability reports in the fast-moving consumer goods sector. Bus. Strateg. Environ. 2018, 27, 1005-1022. [CrossRef]

4. Sassanelli, C.; Rosa, P.; Rocca, R.; Terzi, S. Circular economy performance assessment methods: A systematic literature review. J. Clean. Prod. 2019, 229, 440-453. [CrossRef]

5. Kiselev, A.; Magaril, E.; Magaril, R.; Panepinto, D.; Ravina, M.; Zanetti, M.C.; Kiselev, A.; Magaril, E.; Magaril, R.; Panepinto, D.; et al. Towards circular economy: Evaluation of sewage sludge biogas solutions. Resources 2019, 8, 91. [CrossRef]

6. Cucchiella, F.; D'Adamo, I.; Gastaldi, M. Biomethane: A renewable resource as vehicle fuel. Resources 2017, 6, 58. [CrossRef]

7. Plastinina, I.; Teslyuk, L.; Dukmasova, N.; Pikalova, E.; Plastinina, I.; Teslyuk, L.; Dukmasova, N.; Pikalova, E. Implementation of circular economy principles in regional solid municipal waste management: The case of Sverdlovskaya oblast (Russian federation). Resources 2019, 8, 90. [CrossRef]

8. Gontard, N.; Sonesson, U.; Birkved, M.; Majone, M.; Bolzonella, D.; Celli, A.; Angellier-Coussy, H.; Jang, G.-W.; Verniquet, A.; Broeze, J.; et al. A research challenge vision regarding management of agricultural waste in a circular bio-based economy. Crit. Rev. Environ. Sci. Technol. 2018, 48, 614-654. [CrossRef]

9. Bresciani, S.; Ferraris, A.; Santoro, G.; Nilsen, H.R. Wine sector: Companies' performance and green economy as a means of societal marketing. J. Promot. Manag. 2016, 22, 251-267. [CrossRef]

10. Guarino, F.; Falcone, G.; Stillitano, T.; De Luca, A.I.; Gulisano, G.; Mistretta, M.; Strano, A. Life cycle assessment of olive oil: A case study in southern Italy. J. Environ. Manag. 2019, 238, 396-407. [CrossRef]

11. Carranco, N.; Farrés-Cebrián, M.; Saurina, J.; Núñez, O. Authentication and quantitation of fraud in extra virgin olive oils based on HPLC-UV fingerprinting and multivariate calibration. Foods 2018, 7, 44. [CrossRef]

12. The International Olive Oil Council Publications. Available online: http://www.internationaloliveoil.org/ (accessed on 8 January 2019).

13. European Parliamentary Research Service the EU Olive and Olive Oil Sector Main Features, Challenges and Prospects. Available online: https://ec.europa.eu/agriculture/index_en (accessed on 13 January 2019).

14. Choi, H.S.; Grethe, H.; Entenmann, S.K.; Wiesmeth, M.; Blesl, M.; Wagner, M. Potential trade-offs of employing perennial biomass crops for the bioeconomy in the EU by 2050: Impacts on agricultural markets in the EU and the world. GCB Bioenergy 2019, 11, 483-504. [CrossRef]

15. Asada, R.; Stern, T. Competitive bioeconomy? Comparing bio-based and non-bio-based primary sectors of the world. Ecol. Econ. 2018, 149, 120-128. [CrossRef]

16. International Olive Oil Council. Guide for the Determination of the Characteristics of Oil-Olives; International Olive Oil Council: Madrid, Spain, 2011. 
17. Arpón, A.; Milagro, F.; Razquin, C.; Corella, D.; Estruch, R.; Fitó, M.; Marti, A.; Martínez-González, M.; Ros, E.; Salas-Salvadó, J.; et al. Impact of consuming extra-virgin olive oil or nuts within a Mediterranean diet on DNA methylation in peripheral white blood cells within the PREDIMED-navarra randomized controlled trial: A role for dietary lipids. Nutrients 2017, 10, 15. [CrossRef]

18. D'Adamo, I.; Falcone, P.M.; Gastaldi, M. Price analysis of extra virgin olive oil. Br. Food J. 2019, 121, $1899-1911$. [CrossRef]

19. Chousou, C.; Tsakiridou, E.; Mattas, K. Valuing consumer perceptions of olive oil authenticity. J. Int. Food Agribus. Mark. 2018, 30, 1-16. [CrossRef]

20. European Commission. Commission Delegated Regulation (EU) 2018/1096. Available online: https://eur-lex.europa.eu/eli/reg_del/2018/1096/oj (accessed on 3 January 2019).

21. Perito, M.A.; Sacchetti, G.; Di Mattia, C.D.; Chiodo, E.; Pittia, P.; Saguy, I.S.; Cohen, E. Buy local! Familiarity and preferences for extra virgin olive oil of Italian consumers. J. Food Prod. Mark. 2019, 25, 462-477. [CrossRef]

22. Gonzalez-Fernandez, I.; Iglesias-Otero, M.A.; Esteki, M.; Moldes, O.A.; Mejuto, J.C.; Simal-Gandara, J. A critical review on the use of artificial neural networks in olive oil production, characterization and authentication. Crit. Rev. Food Sci. Nutr. 2019, 59, 1913-1926. [CrossRef]

23. Sayadi, S.; Erraach, Y.; Parra-López, C. Translating consumer's olive-oil quality-attribute requirements into optimal olive-growing practices: A quality function deployment (QFD) approach. Br. Food J. 2017, 119, 190-214. [CrossRef]

24. Cacchiarelli, L.; Carbone, A.; Laureti, T.; Sorrentino, A. The value of the certifications of origin: A comparison between the Italian olive oil and wine markets. Br. Food J. 2016, 118, 824-839. [CrossRef]

25. Rombach, M.; Widmar, N.O.; Byrd, E.; Bitsch, V. Do all roses smell equally sweet? Willingness to pay for flower attributes in specialized retail settings by German consumers. J. Retail. Consum. Serv. 2018, 40, 91-99. [CrossRef]

26. Abbatangelo, M.; Núñez-Carmona, E.; Duina, G.; Sberveglieri, V. Multidisciplinary approach to characterizing the fingerprint of Italian EVoO. Molecules 2019, 24, 1457. [CrossRef] [PubMed]

27. Gorgitano, M.T.; Sodano, V. Differentiation policies in the italian market of extra virgin olive oil. Qual. Access Success 2019, 20, 274-279.

28. Lude, M.; Prügl, R. Why the family business brand matters: Brand authenticity and the family firm trust inference. J. Bus. Res. 2018, 89, 121-134. [CrossRef]

29. European Commission. Family Business. Available online: https://ec.europa.eu/growth/smes/promotingentrepreneurship/we-work-for/family-business_en (accessed on 18 October 2018).

30. De Massis, A.; Sieger, P.; Chua, J.H.; Vismara, S. Incumbents' attitude toward intrafamily succession: An investigation of its antecedents. Fam. Bus. Rev. 2016, 29, 278-300. [CrossRef]

31. De la Cruz Vicente, O.; López Castro, V.I.; Mata Mata, L.; Tomé Bermejo, F. BFE model-business, family and environment-as subsystems of the family-owned business in Mexico City metropolitan area. Resources 2019, 8, 96. [CrossRef]

32. Shaharudin, M.S.; Fernando, Y.; Chiappetta Jabbour, C.J.; Sroufe, R.; Jasmi, M.F.A. Past, present, and future low carbon supply chain management: A content review using social network analysis. J. Clean. Prod. 2019, 218, 629-643. [CrossRef]

33. Gómez-Mejía, L.R.; Haynes, K.T.; Jacobson, K.J.L.; Núñez-Nickel, M.; Moyano-Fuentes, J. Socioemotional wealth and business risks in family-controlled firms: Evidence from Spanish olive oil mills. Adm. Sci. Q. 2017, 52, 106-137. [CrossRef]

34. Marques, P.; Presas, P.; Simon, A. The heterogeneity of family firms in CSR engagement: The role of values. Fam. Bus. Rev. 2014, 27, 206-227. [CrossRef]

35. Miller, D.; Le Breton-Miller, I. Family governance and firm performance: Agency, stewardship, and capabilities. Fam. Bus. Rev. 2006, 19, 73-87. [CrossRef]

36. Kalm, M.; Gomez-Mejia, L.R. Socioemotional wealth preservation in family firms. Rev. Adm. 2016, 51, 409-411. [CrossRef]

37. Núñez-Cacho, P.; Molina-Moreno, V.; Corpas-Iglesias, F.A.; Cortés-García, F.J. Family businesses transitioning to a circular economy model: The case of 'Mercadona'. Sustainability 2018, 10, 538. [CrossRef]

38. Debicki, B.J.; Kellermanns, F.W.; Chrisman, J.J.; Pearson, A.W.; Spencer, B.A. Development of a socioemotional wealth importance (SEWi) scale for family firm research. J. Fam. Bus. Strateg. 2016, 7, 47-57. [CrossRef] 
39. European Commission. The EU Olive and Olive Oil Sector Main Features, Challenges and Prospects. Available online: https://ec.europa.eu/agriculture/olive-oil_en (accessed on 9 October 2018).

40. Berrone, P.; Cruz, C.; Gomez-Mejia, L.R.; Larraza-Kintana, M. Socioemotional wealth and corporate responses to institutional pressures: Do family-controlled firms pollute less? Adm. Sci. Q. 2010, 55, 82-113. [CrossRef]

41. Moragues-Faus, A. How is agriculture reproduced? Unfolding farmers' interdependencies in small-scale Mediterranean olive oil production. J. Rural Stud. 2014, 34, 139-151. [CrossRef]

42. Crespo, M.; Tomé-Carneiro, J.; Dávalos, A.; Visioli, F. Pharma-nutritional properties of olive oil phenols. Transfer of new findings to human nutrition. Foods 2018, 7, 90. [CrossRef]

43. Paladino, O.; Neviani, M. A closed loop biowaste to biofuel integrated process fed with waste frying oil, organic waste and algal biomass: Feasibility at pilot scale. Renew. Energy 2018, 124, 61-74. [CrossRef]

44. Ingrao, C.; Bacenetti, J.; Adamczyk, J.; Ferrante, V.; Messineo, A.; Huisingh, D. Investigating energy and environmental issues of agro-biogas derived energy systems: A comprehensive review of Life Cycle Assessments. Renew. Energy 2019, 136, 296-307. [CrossRef]

45. Galati, A.; Schifani, G.; Crescimanno, M.; Vrontis, D.; Migliore, G. Innovation strategies geared toward the circular economy: A case study of the organic olive-oil industry. Rev. Stud. Sustain. 2018, 1, 137-158. [CrossRef]

46. Homrich, A.S.; Theodoro, D.S.; Carvalho, M.M. PSS creating business for sustainability: The Brazilian olive oil case in Mantiqueira community. Proced. CIRP 2017, 64, 405-410. [CrossRef]

47. Ho, F.H.; Abdul-Rashid, S.H.; Ghazilla, R.; Ariffin, R.; Woo, Y.L. Resources sustainability through material efficiency strategies: An insight study of electrical and electronic companies. Resources 2019, 8, 117. [CrossRef]

48. Laurenti, R.; Martin, M.; Stenmarck, A. Developing adequate communication of waste footprints of products for a circular economy-A stakeholder consultation. Resources 2018, 7, 78. [CrossRef]

49. Berbel, J.; Posadillo, A. Review and analysis of alternatives for the valorisation of agro-industrial olive oil by-products. Sustainability 2018, 10, 237. [CrossRef]

50. Batuecas, E.; Tommasi, T.; Battista, F.; Negro, V.; Sonetti, G.; Viotti, P.; Fino, D.; Mancini, G. Life cycle assessment of waste disposal from olive oil production: Anaerobic digestion and conventional disposal on soil. J. Environ. Manag. 2019, 237, 94-102. [CrossRef] [PubMed]

51. Del Pozo, C.; Bartrolí, J.; Puy, N.; Fàbregas, E. Separation of value-added chemical groups from bio-oil of olive mill waste. Ind. Crops Prod. 2018, 125, 160-167. [CrossRef]

52. Hamelin, L.; Borzecka, M.; Kozak, M.; Pudełko, R. A spatial approach to bioeconomy: Quantifying the residual biomass potential in the EU-27. Renew. Sustain. Energy Rev. 2019, 100, 127-142. [CrossRef]

53. Delisi, R.; Ciriminna, R.; Arvati, S.; Meneguzzo, F.; Pagliaro, M. Olive biophenol integral extraction at a two-phase olive mill. J. Clean. Prod. 2018, 174, 1487-1491. [CrossRef]

54. Galliou, F.; Markakis, N.; Fountoulakis, M.S.; Nikolaidis, N.; Manios, T. Production of organic fertilizer from olive mill wastewater by combining solar greenhouse drying and composting. Waste Manag. 2018, 75, 305-311. [CrossRef] [PubMed]

55. La Scalia, G.; Micale, R.; Cannizzaro, L.; Marra, F.P. A sustainable phenolic compound extraction system from olive oil mill wastewater. J. Clean. Prod. 2017, 142, 3782-3788. [CrossRef]

56. Lanfranchi, M.; Giannetto, C.; De Pascale, A. Economic analysis and energy valorization of by-products of the olive oil process: 'Valdemone DOP' extra virgin olive oil. Renew. Sustain. Energy Rev. 2016, 57, 1227-1236. [CrossRef]

57. Pellegrini, G.; Ingrao, C.; Camposeo, S.; Tricase, C.; Contò, F.; Huisingh, D. Application of water footprint to olive growing systems in the Apulia region: A comparative assessment. J. Clean. Prod. 2016, 112, 2407-2418. [CrossRef]

58. Clodoveo, M.L. Industrial ultrasound applications in the extra-virgin olive oil extraction process: History, approaches, and key questions. Foods 2019, 8, 121. [CrossRef] [PubMed]

59. Karanikolasa, P.; Correiab, T.P.; Martinez-Gomezc, V.; Gallid, F.; Hernandeze, P.A.; Fastellif, L.; Arnalte-Murg, L.; Mendezh, M.R.; Prosperii, P.; Goussiosj, G. Food system integration of olive oil producing small farms: A comparative study of four Mediterranean regions. In Proceedings of the 13th European International Farming Systems Association (IFSA) Symposium, Farming Systems: Facing Uncertainties and Enhancing Opportunities, Chania, Crete, Greece, 1-5 July 2018; pp. 1-20.

60. Falcone, P.M.; Tani, A.; Tartiu, V.E.; Imbriani, C. Towards a sustainable forest-based bioeconomy in Italy: Findings from a SWOT analysis. For. Policy Econ. 2019. [CrossRef] 
61. Reißmann, D.; Thrän, D.; Bezama, A. Techno-economic and environmental suitability criteria of hydrothermal processes for treating biogenic residues: A SWOT analysis approach. J. Clean. Prod. 2018, 200, 293-304. [CrossRef]

62. Farré-Ribes, M.; Lozano-Cabedo, C.; Aguilar-Criado, E. The role of knowledge in constructing the quality of olive oil in Spain. Sustainability 2019, 11, 4029. [CrossRef]

63. Robinson, O.C. Sampling in interview-based qualitative research: A theoretical and practical guide. Qual. Res. Psychol. 2014, 11, 25-41. [CrossRef]

64. Conrad, C.F.; Serlin, R.C. The Sage Handbook for Research in Education: Engaging Ideas and Enriching Inquiry; Sage Publications: Tauzand Ouks, CA, USA, 2005; ISBN 141297335X.

65. Falcone, P.M.; Morone, P.; Sica, E. Greening of the financial system and fuelling a sustainability transition: A discursive approach to assess landscape pressures on the Italian financial system. Technol. Forecast. Soc. Chang. 2018, 127, 23-37. [CrossRef]

66. Blasi, F.; Pollini, L.; Cossignani, L. Varietal authentication of extra virgin olive oils by triacylglycerols and volatiles analysis. Foods 2019, 8, 58. [CrossRef] [PubMed]

67. Jeong, J.S.; García-Moruno, L. The study of building integration into the surrounding rural landscape: Focus on implementation of a web-based MC-SDSS and its validation by two-way participation. Land Use Policy 2016, 57, 719-729. [CrossRef]

68. Panico, T.; Del Giudice, T.; Caracciolo, F. Quality dimensions and consumer preferences: A choice experiment in the Italian extra-virgin olive oil market. Agric. Econ. Rev. 2014, 15, 13.

69. Cohen, M.; Lepesant, G.; Lamari, F.; Bilodeau, C.; Benyei, P.; Angles, S.; Bouillon, J.; Bourrand, K.; Landoulsi, R.; Jaboeuf, D.; et al. Biomolecules from olive pruning waste in Sierra Mágina-Engaging the energy transition by multi-actor and multidisciplinary analyses. J. Environ. Manag. 2018, 216, 204-213. [CrossRef]

70. Valli, E.; Bendini, A.; Popp, M.; Bongartz, A. Sensory analysis and consumer acceptance of 140 high-quality extra virgin olive oils. J. Sci. Food Agric. 2014, 94, 2124-2132. [CrossRef] [PubMed]

71. Serreli, G.; Deiana, M. Biological relevance of extra virgin olive oil polyphenols metabolites. Antioxidants 2018, 7, 170. [CrossRef] [PubMed]

72. Currò, M.; Russo, T.; Ferlazzo, N.; Caccamo, D.; Antonuccio, P.; Arena, S.; Parisi, S.; Perrone, P.; Ientile, R.; Romeo, C.; et al. Anti-inflammatory and tissue regenerative effects of topical treatment with ozonated Olive oil/vitamin E acetate in balanitis xerotica obliterans. Molecules 2018, 23, 645. [CrossRef] [PubMed]

73. Planning Tank. Techniques of SWOT Analysis-Strategic Planning Method. Available online: https://planningtank.com/planning-techniques/swot-analysis (accessed on 5 August 2019).

74. Romero-Gámez, M.; Castro-Rodríguez, J.; Suárez-Rey, E.M. Optimization of olive growing practices in Spain from a life cycle assessment perspective. J. Clean. Prod. 2017, 149, 25-37. [CrossRef]

75. Rodríguez Cohard, J.C.; Sánchez Martínez, J.D.; Gallego Simón, V.J. The upgrading strategy of olive oil producers in Southern Spain: Origin, development and constraints. Rural Soc. 2017, 26, 30-47. [CrossRef]

76. Fiorini, D.; Boarelli, M.C.; Conti, P.; Alfei, B.; Caprioli, G.; Ricciutelli, M.; Sagratini, G.; Fedeli, D.; Gabbianelli, R.; Pacetti, D. Chemical and sensory differences between high price and low price extra virgin olive oils. Food Res. Int. 2018, 105, 65-75. [CrossRef]

77. Cavallo, C.; Caracciolo, F.; Cicia, G.; Del Giudice, T. Extra-virgin olive oil: Are consumers provided with the sensory quality they want? A hedonic price model with sensory attributes. J. Sci. Food Agric. 2018, 98, 1591-1598. [CrossRef]

(C) 2019 by the authors. Licensee MDPI, Basel, Switzerland. This article is an open access article distributed under the terms and conditions of the Creative Commons Attribution (CC BY) license (http://creativecommons.org/licenses/by/4.0/). 